\begin{tabular}{|ll} 
Journal of & Publiser \\
\hline MandagementReview & $\begin{array}{l}\text { Graduate Program Universitas Galuh } \\
\text { Master Manajemen Studies Program } \\
\text { Co2017 }\end{array}$
\end{tabular}

\title{
PENGARUH REWARD DAN PUNISHMENT TERHADAP KEPUASAN KERJA DAN IMPLIKASINYA ATAS KINERJA BENDAHARA PENGELUARAN DI PEMERINTAH KOTA BANJAR
}

\author{
Nursaadah $^{1}$ \\ ${ }^{1}$ Program Studi Manajemen Pascasarjana Universitas Galuh Ciamis \\ e-mail :pascaunigal@gmail.com
}

Article History :
Recieved 5 December 2016
Recieved in revished form
21 December 2016
Acepted 5 Januari 2017
Available offline 20 Januari 2017
Available online 20 Januari 2017

Language Transcript :

Indonesia

Key Words :

Reward

Punishment

Kepuasan Kerja

Kinerja Bendahara

Pengeluaran

\begin{abstract}
Tulisan ini adalah untuk mempelajari, mengetahui, dan menganalisis Pengaruh Reward dan Punishment terhadap Kepuasan Kerja dan Implikasinya atas Kinerja Bendahara Pengeluaran di Pemerintah Kota Banjar. Sedangkan metode yang digunakan dalam penelitian ini adalah survey explanatory dengan pendekatan kuantitatif, sedangkan teknis analisis data, yaitu statistik deskriptif Analisis dan Statistik Induktif (Inferensial) dengan menggunakan analisis jalur (Path Analysis). Hasil penelitian dan pembahasan memperlihatkan bahwa (1) Reward berpengaruh terhadap kepuasan kerja bendahara pengeluaran. Artinya jika reward ditingkatkan, maka kepuasan kerja bendahara pengeluaran akan meningkat pula. Dengan demikian hipotesis 1 dapat teruji kebenarannya atau Signifikan karena $t_{\text {hitung }} 3,493>t_{\text {tabel }} 2,030$ dengan $p$-Value 0,001. (2) Punishment berpengaruh terhadap kepuasan kerja bendahara pengeluaran. Artinya jika punishment ditingkatkan, maka kepuasan kerja bendahara pengeluaran akan meningkat pula. Dengan demikian hipotesis 2 dapat teruji kebenarannya atau Signifikan karena $t_{\text {hitung }} 6,145>t_{\text {tabel }} 2,030$ dengan $p$-Value 0,000. (3) Reward dan punishment berpengaruh terhadap kepuasan kerja bendahara pengeluaran. Artinya jika reward dan punishment ditingkatkan, maka kepuasan kerja bendahara pengeluaran akan meningkat pula. Dengan demikian hipotesis 3 dapat teruji kebenarannya atau Signifikan karena $F_{\text {hitung }} 94,101$ $>F_{\text {tabel }}$ 3,20 dengan p-Value 0,000. (4) Kepuasan Kerja berpengaruh positif terhadap kinerja bendahara pengeluaran. Artinya jika kepuasan kerja ditingkatkan, maka kinerja bendahara pengeluaran akan meningkat pula. Dengan demikian hipotesis 4 dapat teruji kebenarannya atau Signifikan karena $_{\text {hitung }} 3,404>t_{\text {tabel }} 2,030$ dengan p-Value 0,002.
\end{abstract}

\section{PENDAhUluan}

Sumber Daya Manusia (SDM) merupakan aset penting bagi suatu organisasi untuk mencapai tujuan organisasi. Pengembangan dan pengelolaan sumber daya manusia secara efektif mampu meningkatkan kinerja pegawai. Sistem pengendalian manajemen menjadi alat untuk mengembangkan dan mengelola SDM organisasi.
Sistem pengendalian manajemen fokus pada output, dimana penekanan pada motivasi pegawai, dengan memperkuat reward dan punishment. Sistem reward dan punishment menjadi alat untuk memotivasi pegawai agar mencapai kepuasan kerja dan meningkatkan kinerja pegawai demi tercapainya tujuan organisasi.

Pemerintah Kota Banjar merupakan salah satu organisasi Pemerintah Daerah yang 
tidak terlepas dari keinginan untuk mewujudkan tercapainya tujuan organisasi pemerintah yang memiliki komitmen didalam pengelolaan keuangan dan aset daerah. Pemerintah Kota Banjar mempunyai tujuan dalam pengelolaan keuangan dan aset daerah yaitu mewujudkan tata kelola keuangan dan aset yang transparan, akuntabel dan dilaksanakan secara profesional. Disamping itu pula Pemerintah Kota Banjar berkomitmen untuk mempertahankan peringkat tertinggi penilaian dari Badan Pemeriksa Keuangan (BPK) yaitu Opini Wajar Tanpa Pengecualian (WTP) untuk laporan keuangan daerah setiap tahunnya.

Untuk mewujudkan tujuan tersebut, profesionalisme pejabat pengelola keuangan yang berkecimpung langsung didalamnya merupakan suatu keharusan yang tidak dapat ditawar lagi. Salah satu faktor yang sangat mempengaruhi keberhasilan Pemerintah Kota Banjar dalam mencapai tujuan tersebut adalah Sumber Daya Manusia (SDM) dalam hal ini Pegawai Negeri Sipil (PNS) yang menjadi pejabat pengelola keuangan di Organisasi Perangkat Daerah (OPD) masing-masing. Pejabat pengelola keuangan di OPD diantaranya adalah bendahara pengeluaran, bendahara penerimaan dan pengurus barang.

Tidak dapat dipungkiri masih banyak kendala yang dihadapi oleh Pemerintah Kota Banjar untuk mewujudkan tujuan menjadi salah satu Pemerintah Daerah yang mengelola keuangan dan aset yang handal. Hal ini disebabkan keterbatasan SDM yang memiliki keahlian di bidangnya baik dari kualitas maupun kuantitas.

Dalam meningkatkan kinerja maka faktor penting yang harus ditingkatkan adalah kepuasan kerja. Kepuasan kerja pegawai berkaitan dengan pengembangan sumber daya manusia yang merupakan kunci keberhasilan. Sumber daya manusia yang berkualitas akan mampu meningkatkan kepuasan kerja pegawai.

Menurut Herzberg (dalam Hasibuan, 2005:15) mengemukakan bahwa istilah kepuasan kerja (job satisfaction) dapat didefinisikan sebagai suatu perasaan positif yang merupakan hasil dari sebuah evaluasi karakteristiknya. Setiap pegawai memiliki tingkat kepuasan kerja yang berbeda-beda. Hal ini disebabkan karena setiap individu memiliki kemampuan yang berbeda dalam hal menangkap suatu pengetahuan dan keterampilan. Selain sifat dari setiap individu itu sendiri juga banyak berpengaruh terhadap kemampuan diri individu tersebut. Oleh karena itu pihak manajemen melakukan berbagai upaya untuk menunjang terciptanya kepuasan kerja yang tinggi pada diri pegawainya.

Pemberian reward atau penghargaan kepada pegawai yang berprestasi akan memberikan motivasi kepada pegawai untuk lebih meningkatkan kinerjanya dan memberikan kepuasan kerja. Semakin tinggi tingkat kinerja pegawai maka semakin cepat tercapainya tujuan organisasi.

Keinginan mengakhiri tugas atau meninggalkan organisasi berhubungan negatif dengan kepuasan kerja. Pegawai yang merasa terpuaskan dengan pekerjaannya cenderung untuk bertahan dalam organisasi dan sebaliknya. Dampak ketidakpuasan selain dalam bentuk meninggalkan pekerjaan dapat juga berupa ketidakhadiran. Untuk meningkatkan kepuasan kerja dapat diberikan reward berupa pemberian imbalan atau membenahi struktur penggajian.

Selain reward atau penghargaan, organisasi juga harus memberikan sanksi atau punishment kepada pegawai yang malas atau lalai dalam bekerja karena hal itu akan mengganggu kinerja pegawai. Dengan pemberian sanksi yang sesuai maka diharapkan akan meningkatkan kepuasan 
kerja dan kinerja pegawai. Seperti halnya reward, punishment menjadi salah satu alat untuk memprediksi kinerja pegawai serta kepuasan kerja. Punishment diberikan kepada pegawai yang terbukti melakukan pelanggaran terhadap aturan yang telah ditentukan.

Pada Pemerintah Kota Banjar pada kenyataannya menunjukkan bahwa tunjangan yang diberikan belum sesuai karena banyak bendahara pengeluaran merangkap jabatan menjadi pengurus barang dalam satu OPD sehingga beban kerjanya bertambah, masih ada bendahara pengeluaran yang ingin mengundurkan diri dari jabatannya karena penghargaan yang diberikan tidak sesuai dengan beban kerja yang dilakukan, belum adanya sanksi terhadap Bendahara pengeluaran yang tidak melaporkan Daftar Transaksi Harian (DTH) tepat waktu setiap bulannya, belum adanya sanksi terhadap bendahara pengeluaran yang tidak menyerahkan laporan fungsional setiap bulan secara teratur, dan tidak mengikuti standar yang telah ditetapkan, tingkat penghargaan yang diberikan atasan belum sesuai dengan yang diharapkan, pelimpahan pekerjaan belum disertai penjelasan yang lengkap kepada penerimanya, masih terdapat bendahara pengeluaran yang terlambat menyerahkan laporan fungsional atau Surat Pertanggungjawaban Fungsional setiap bulannya, dan masih terdapat laporan yang sering salah sehingga perlu diperbaiki yang mengakibatkan Laporan Keuangan Pemerintah Daerah terlambat.

\section{METOOLOGI}

Metode yang digunakan dalam penelitian ini adalah survey explanatory. Menurut Kerlinger yang dikutip oleh Sugiyono (2010:17) "metode survey yaitu metodologi penelitian yang digunakan pada populasi besar maupun kecil, tetapi data yang dipelajari adalah data dari sampel yang diambil dari populasi tersebut, sehingga ditemukan kejadian-kejadian relatif, distribusi dan hubungan-hubungan antar variabel sosiologis maupun psikologis.

Desain/jenis penelitian yang akan digunakan dalam penyusunan tesis ini adalah desain penelitian kuantitatif yaitu desain yang dilakukan pada empirik tidak secara mendalam melainkan meluas, untuk memperoleh pengetahuan ilmiah yang bersifat abstrak, general dan universal (Rusidi dan Enas, 2011:27).

Tempat/lokasi penelitian dilakukan di OPD Pemerintah Kota Banjar, dan waktu penelitian adalah bulan Oktober 2015 s.d Mei 2016.

Objek penelitian terdiri dari dua elemen, yaitu populasi dan sampel. Populasi dalam penelitian ini adalah OPD Pemerintah Kota Banjar sebanyak 37 orang. Proses pengambilan sampel dalam penelitian ini adalah dengan sampling jenuh atau sensus. Pengertian dari sampling jenuh atau sensus menurut Sugiyono (2008:122), adalah teknik penentuan sampel bila semua anggota populasi digunakan sebagai sampel" sehingga peneliti mengambil jumlah sampel sama dengan jumlah populasi atau disebut dengan sensus yaitu seluruh bendahara pengeluaran pada OPD Pemerintah Kota Banjar sebanyak 37 orang.

Data yang digunakan dalam penelitian ini adalah data primer dan data sekunder. Sumber data primer diperoleh dari hasil penyebaran angket kepada seluruh bendahara pengeluaran Pemerintah Kota Banjar, sedangkan data sekunder diperoleh dari OPD Pemerintah Kota Banjar.

Teknik dan instrumen pengumpulan data diusahakan untuk mendapatkan data yang dibutuhkan dalam analisis tesis ini. Pengumpulan data tersebut meliputi:

1) Observasi, yaitu mengamati kegiatan di OPD Pemerintah Kota Banjar. 
2) Kuesioner, yang diberikan kepada seluruh bendahara pengeluaran di Pemerintah Kota Banjar, dengan cara mengajukan pertanyaan yang secara logis berhubungan dengan masalah penelitian dan bersifat pertanyaan tertutup/berstruktur yang menyangkut pendapat responden tentang pengaruh pengaruh Reward dan Punishment terhadap Kepuasan Kerja dan Implikasinya atas Kinerja Bendahara Pengeluaran.

Teknik Analisis data yang digunakan dalam penelitian ini adalah:

1) Uji validitas

Uji Validitas ini dimaksudkan untuk menguji seberapa baik instrument penelitian mengukur konsep yang seharusnya diukur. Untuk mengetahui apakah item-item pertanyaan yang tersaji dalam kuesionar benar-benar mempu mengungkapkan dengan pasti tentang apa yang akan diteliti.

2) Uji Reliabilitas

\begin{tabular}{|c|c|}
\hline $\begin{array}{l}\text { Koefisien } \\
\text { dimaksudkan } \\
\text { konsistensi }\end{array}$ & $\begin{array}{cr}\text { reliabilitas } & \text { istrumen } \\
\text { untuk } & \text { melihat } \\
\text { jawaban } & \text { butir-butir }\end{array}$ \\
\hline & diberikan ol \\
\hline
\end{tabular}

3) Statistik deskriptif

Teknik analisis statistik deskriptif yang digunakan dalam penelitian ini adalah untuk mengetahui karakteristik responden dan untuk mengetahui kriteria deskripsi dari masing-masing variabel yang diteliti.

4) Analisis Statistik Induktif (Inferensial), yaitu

Analisis yang digunakan untuk menguji pengaruh variabel independen terhadap variabel dependen adalah analisis jalur (Analysis Path) yaitu untuk menganalisis hubungan sebab akibat yang terjadi antara variabel bebas dan terikat baik secara langsung maupun tidak langsung.

\section{HASIL DAN PEMBAHASAN 1) Hasil Penelitian}

Berikut ini adalah hasil pengaruh Reward $\left(\mathrm{X}_{1}\right)$ dan Punishment $\left(\mathrm{X}_{2}\right)$ terhadap Kepuasan Kerja (Y) dan Implikasinya atas Kinerja Bendahara Pengeluaran (Z) di Pemerintah Kota Banjar menggunakan program SPSS yang penulis sajikan dalam Tabel. 1. sebagai berikut:

Tabel 1 Hasil Rekapitulasi Pengaruh Reward $\left(\mathrm{X}_{1}\right)$ dan Punishment $\left(\mathrm{X}_{2}\right)$ terhadap Kepuasan Kerja (Y) dan Implikasinya Atas Kinerja Bendahara Pengeluaran (Z)

\begin{tabular}{ccccccc}
\hline Variabel & $\mathrm{R}$ & $\begin{array}{c}\mathrm{R} \\
\text { Square }\end{array}$ & Beta & $\mathrm{t}$ & $\mathrm{F}$ & $\mathrm{Sig}$ \\
\hline $\mathrm{X}_{1}-\mathrm{Y}$ & 0,890 & 0,792 & 0,505 & 3,493 & - & 0,001 \\
$\mathrm{X}_{2}-\mathrm{Y}$ & 0,882 & 0,778 & 0,451 & 6,145 & - & 0,000 \\
$\mathrm{X}_{1} \mathrm{X}_{2}-\mathrm{Y}$ & 0,920 & 0,847 & 0,956 & - & 94,101 & 0,000 \\
$\mathrm{Y}-\mathrm{Z}$ & 0,563 & 0,317 & 0,563 & 3,404 & - & 0,002 \\
\hline
\end{tabular}

\section{A. Pengaruh Reward ( $\left.\mathrm{X}_{1}\right)$ Terhadap Kepuasan Kerja Bendahara Pengeluaran (Y).}

Berdasarkan Tabel 1. diketahui bahwa hubungan antara variabel Reward $\left(\mathrm{X}_{1}\right)$ dengan Kepuasan Kerja Bendahara Pengeluaran (Y) yang dihitung dengan koefisien korelasi adalah 0,890. Berdasarkan tabel 3.3. angka tersebut menunjukkan bahwa terdapat hubungan yang sangat tinggi antara variabel $\left(\mathrm{X}_{1}\right)$ dengan (Y). Untuk menyatakan besar kecilnya kontribusi (sumbangan) variabel $\left(\mathrm{X}_{1}\right)$ terhadap (Y), dapat dilihat bahwa koefisien determinan sebesar 0,792. Artinya kepuasan kerja bendahara pengeluaran dipengaruhi oleh Reward sebesar 79,2\%, sedangkan sisanya sebesar 20,8\% dipengaruhi faktor lain yang tidak diteliti. Dengan demikian dapat disimpulkan bahwa terdapat pengaruh antara variabel Reward 
$\left(\mathrm{X}_{1}\right)$ terhadap kepuasan kerja bendahara pengeluaran $(\mathrm{Y})$.

Berdasarkan hasil analisis regresi linier $(\mathrm{Y}=$ $\mathrm{a}+\mathrm{b} 1 \mathrm{X}_{1}$ ) pada analisa pengaruh reward terhadap kepuasan kerja bendahara pengeluaran diperoleh nilai $\mathrm{a}=1,006$ dan nilai $b$ sebesar 0,760 . Berdasarkan nilai tersebut, diperoleh persamaan regresi yang menggambarkan skor ramalan kepuasan kerja bendahara pengeluaran berdasarkan reward sebagai berikut: $\mathrm{Y}=1,006+$ $0,760 X_{1}$. Artinya jika $X_{1}$ dinaikkan $1 \%$ maka Y naik 0,760 .

Berdasarkan tabel 4.59. tersebut pun dapat dilihat bahwa nilai $\mathrm{t}$ hitung adalah sebesar 3,493 dengan signifikasi $0,001<0,05$. Dan nilai $\mathrm{t}$ tabel dengan $\mathrm{df}=37-2=35$ pada tingkat signifikasi 5\% adalah sebesar 2,030. Dengan demikian, karena $t_{\text {hitung }} 3,493>t_{\text {tabel }}$ 2,030, dapat disimpulkan bahwa Ho ditolak. Artinya, terdapat pengaruh antara variabel reward $\left(\mathrm{X}_{1}\right)$ terhadap kepuasan kerja bendahara pengeluaran $(\mathrm{Y})$.

\section{B. Pengaruh Punishment $\left(\mathbf{X}_{2}\right)$ terhadap Kepuasan Kerja Bendahara Pengeluaran (Y).}

Berdasarkan Tabel 1. diketahui bahwa hubungan antara variabel Punishment $\left(\mathrm{X}_{2}\right)$ dengan Kepuasan Kerja Bendahara Pengeluaran (Y) yang dihitung dengan koefisien korelasi adalah 0,882. Berdasarkan Tabel 1. angka tersebut menunjukkan bahwa terdapat hubungan yang sangat tinggi antara variabel $\left(\mathrm{X}_{2}\right)$ dengan (Y). Untuk menyatakan besar kecilnya kontribusi (sumbangan) variabel $\left(\mathrm{X}_{2}\right)$ terhadap $(\mathrm{Y})$, dapat dilihat bahwa koefisien determinan sebesar 0,778. Artinya kepuasan kerja bendahara pengeluaran dipengaruhi oleh punishment sebesar $77,8 \%$, sedangkan sisanya sebesar $22,2 \%$ dipengaruhi faktor lain yang tidak diteliti. Dengan demikian dapat disimpulkan bahwa terdapat pengaruh antara variabel punishment $\left(\mathrm{X}_{2}\right)$ terhadap kepuasan kerja bendahara pengeluaran $(\mathrm{Y})$.
Berdasarkan hasil analisis regresi linier $(\mathrm{Y}=$ $\mathrm{a}+\mathrm{b} 2 \mathrm{X}_{2}$ ) pada analisa pengaruh punishment terhadap kepuasan kerja bendahara pengeluaran diperoleh nilai $\mathrm{a}=1,548$ dan nilai $b$ sebesar 0,646 . berdasarkan nilai tersebut, diperoleh persamaan regresi yang menggambarkan skor ramalan kepuasan kerja bendahara pengeluaran berdasarkan punishment sebagai berikut: $\mathrm{Y}=1,548+$ $0,646 \mathrm{X}_{2}$. Artinya jika $\mathrm{X}_{2}$ dinaikkan $1 \%$ maka Y naik 0,646.

Berdasarkan Tabel 1. tersebut pun dapat dilihat bahwa nilai $\mathrm{t}$ hitung adalah sebesar 6,145 dengan signifikasi $0,000<0,05$. Dan nilai $\mathrm{t}$ tabel dengan $\mathrm{df}=37-2=35$ pada tingkat signifikasi 5\% adalah sebesar 2,030. Dengan demikian, karena $t_{\text {hitung }} 6,145>t_{\text {tabel }}$ 2,030, dapat disimpulkan bahwa Ho ditolak. Artinya, terdapat pengaruh antara variabel punishment $\left(\mathrm{X}_{2}\right)$ terhadap kepuasan kerja bendahara pengeluaran $(\mathrm{Y})$.

\section{Pengaruh reward $\left(\mathrm{X}_{1}\right)$ dan Punishment $\quad\left(\mathbf{X}_{2}\right) \quad$ terhadap Kepuasan Kerja Bendahara Pengeluaran (Y).}

Berdasarkan Tabel. 1. diketahui bahwa hubungan antara variabel reward $\left(\mathrm{X}_{1}\right)$ dan punishment $\left(\mathrm{X}_{2}\right)$ dengan kepuasan kerja bendahara pengeluaran $(\mathrm{Y})$ yang dihitung dengan koefisien korelasi adalah 0,920. Berdasarkan tabel 3.3. angka tersebut menunjukkan bahwa terdapat hubungan yang sangat tinggi antara variabel $\left(\mathrm{X}_{1}\right)$ dan $\left(\mathrm{X}_{2}\right)$ dengan $(\mathrm{Y})$. Untuk menyatakan besar kecilnya kontribusi (sumbangan) variabel $\left(\mathrm{X}_{1}\right)$ dan $\left(\mathrm{X}_{2}\right)$ terhadap $(\mathrm{Y})$, dapat dilihat bahwa koefisien determinan sebesar 0,847. Artinya kepuasan kerja bendahara pengeluaran dipengaruhi oleh reward dan punishment sebesar 84,7\%, sedangkan sisanya sebesar $15,3 \%$ dipengaruhi faktor lain yang tidak diteliti. Dengan demikian dapat disimpulkan bahwa terdapat pengaruh antara variabel reward $\left(\mathrm{X}_{1}\right)$ dan punishment $\left(\mathrm{X}_{2}\right)$ terhadap kepuasan kerja bendahara pengeluaran $(\mathrm{Y})$. 
Berdasarkan hasil analisis regresi linier ( $\mathrm{Y}=$ $\left.\mathrm{a}+\mathrm{b} 1 \mathrm{X}_{1}+\mathrm{b} 2 \mathrm{X}_{2}\right)$ pada analisa reward $\left(\mathrm{X}_{1}\right)$ dan punishment $\left(\mathrm{X}_{2}\right)$ terhadap kepuasan kerja bendahara pengeluaran $(\mathrm{Y})$ diperoleh nilai $a=1,026$, $b 1=0,431$, dan $b 2=0,330$ Persamaan regresinya $\mathrm{Y}=1,026+0,431 \mathrm{X}_{1}+0,330 \mathrm{X}_{2}$. Artinya jika $\mathrm{X}_{1}$ dan $\mathrm{X}_{2}$ dinaikkan $1 \%$ maka $\mathrm{Y}$ naik 0,431 dan 0,330 .

Berdasarkan Tabel. 1. dapat dilihat bahwa diperoleh $\mathrm{F}_{\text {hitung }}$ sebesar 94,101 dengan tingkat signifikasi $0,000<0,05$. Dan nilai $\mathrm{F}_{\text {tabel }}$ dengan $\mathrm{dk}=37-2=35$ maka diperoleh $F_{\text {tabel }} 3,25$. Dengan demikian karena $F_{\text {hitung }}$ 94,101 > $\mathrm{F}_{\text {tabel }}$ 3,20, dapat disimpulkan bahwa ho ditolak. Artinya terdapat pengaruh antara reward $\left(\mathrm{X}_{1}\right)$ dan punishment $\left(\mathrm{X}_{2}\right)$ terhadap kinerja pegawai (Y).

\section{Pengaruh Kepuasan Kerja (Y) terhadap Kinerja Bendahara Pengeluaran $(\mathbf{Z})$.}

Berdasarkan Tabel 1. diketahui bahwa hubungan antara variabel kepuasan kerja bendahara pengeluaran (Y) dengan kinerja bendahara pengeluaran $(Z)$ yang dihitung dengan koefisien korelasi adalah 0,563. Berdasarkan tabel 3.3. angka tersebut menunjukkan bahwa terdapat hubungan yang sedang antara variabel (Y) dengan (Z). Untuk menyatakan besar kecilnya kontribusi (sumbangan) variabel (Y) terhadap (Z), dapat dilihat bahwa koefisien determinan sebesar 0,317. Artinya kinerja bendahara pengeluaran dipengaruhi oleh kepuasan kerja sebesar $31,7 \%$, sedangkan sisanya sebesar $68,3 \%$ dipengaruhi faktor lain yang tidak diteliti. Dengan demikian dapat disimpulkan bahwa terdapat pengaruh antara variabel kepuasan kerja (Y) terhadap kinerja bendahara pengeluaran (Z).

Berdasarkan hasil analisis regresi linier $(\mathrm{Z}=$ $a+b Y)$ pada analisa pengaruh kepuasan kerja terhadap kinerja bendahara pengeluaran diperoleh nilai $\mathrm{a}=2,044$ dan nilai $b$ sebesar 0,559 . berdasarkan nilai tersebut, diperoleh persamaan regresi yang menggambarkan skor ramalan kinerja bendahara pengeluaran berdasarkan kepuasan kerja sebagai berikut: $\mathrm{Z}=2,044+$ $0,559 Y$. Artinya jika Y dinaikkan $1 \%$ maka $\mathrm{Z}$ naik 0,559 .

Berdasarkan Tabel 1. tersebut pun dapat dilihat bahwa nilai $\mathrm{t}$ hitung adalah sebesar 3,404 dengan signifikasi $0,002<0,05$. Dan nilai $\mathrm{t}$ tabel dengan $\mathrm{df}=37-2=35$ pada tingkat signifikasi 5\% adalah sebesar 2,030. Dengan demikian, karena $t_{\text {hitung }} 3,404>t_{\text {tabel }}$ 2,030, dapat disimpulkan bahwa Ho ditolak. Artinya, terdapat pengaruh antara variabel kepuasan kerja (Y) terhadap kinerja bendahara pengeluaran (Z).

Berdasarkan Tabel 1. kita bisa menyusun matriks jalur yaitu sebagai berikut:

$\begin{array}{lll}\operatorname{\rho yx}_{1} & =0,505 \\ \operatorname{\rho yx}_{2} & =0,451 \\ \operatorname{pyx}_{1} x_{2} & =0,956 \\ \rho y z & =0,563\end{array}$

Dari Beta tersebut dapat dihitung koefisien jalur variabel lain diluar model yakni $\mathrm{Py} \varepsilon_{1}$ dengan rumus: Py $\varepsilon_{1}=1-0,956=0,044$, dan

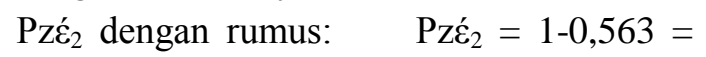
0,437 . Semua perolehan hasil perhitungan di atas dapat digambarkan dalam persamaan sebagai berikut:

$$
\begin{aligned}
& Y=0,505 X_{1}+0,451 X_{2}+0,044 \dot{\varepsilon}_{1} \\
& Z=0,563 Y+0,437 \dot{\varepsilon}_{2}
\end{aligned}
$$

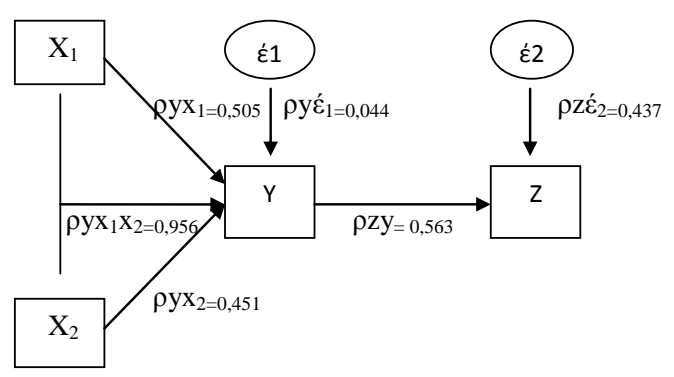

Keterangan:

$$
\text { Gambar 1. Konsep Penelitian }
$$

$$
\begin{array}{rlr}
\operatorname{pyx}_{1=0,505}= & \begin{array}{l}
\text { Koefisien Jalur Reward } \\
\text { terhadap } \quad \text { Kepuasan }
\end{array} & \left(\mathrm{X}_{1}\right) \\
& \text { Kendahara Pengeluaran }(\mathrm{Y})
\end{array}
$$




\begin{tabular}{|c|c|}
\hline$\rho \mathrm{yx}_{2}=0,451$ & $\begin{array}{lll}\text { Koefisien Jalur Punishment } & \left(\mathrm{X}_{2}\right) \\
\text { terhadap } & \text { Kepuasan } & \text { Kerja } \\
\text { Bendahara Pengeluaran }(\mathrm{Y}) & \end{array}$ \\
\hline$\rho \mathrm{yx}_{1} \mathrm{x}_{2}=0,956$ & $\begin{array}{lll}\text { Koefisien Jalur } & \text { Reward } & \left(\mathrm{X}_{1}\right) \text { dan } \\
\text { Punishment } & \left(\mathrm{X}_{2}\right) & \text { terhadap } \\
\text { Kepuasan Kerja } & \text { Bendahara } \\
\text { Pengeluaran }(\mathrm{Y}) & \end{array}$ \\
\hline$\rho y z_{=0,563}$ & $\begin{array}{l}\text { Koefisien Jalur Kepuasan Kerja }(Y) \\
\text { terhadap Kinerja Bendahara } \\
\text { Pengeluaran }(\mathrm{Z}) \text {. }\end{array}$ \\
\hline$\rho y \varepsilon_{1=0,080}$ & $\begin{array}{l}\text { Koefisien Jalur variabel lain }\left(\dot{\varepsilon}_{1}\right) \\
\text { terhadap Kepuasan } \\
\text { Bendahara Pengeluaran }(Y) \text { Kerja }\end{array}$ \\
\hline$\rho z \dot{\varepsilon}_{2=0,437}$ & $\begin{array}{l}\text { Koefisien Jalur variabel lain }\left(\dot{\varepsilon}_{2}\right) \\
\text { terhadap Kinerja Bendahara } \\
\text { Pengeluaran }(\mathrm{Z}) \text {. }\end{array}$ \\
\hline
\end{tabular}

\section{2) Pembahasan}

\section{A. Pengaruh Reward $\left(\mathrm{X}_{1}\right)$ terhadap Kepuasan Kerja Bendahara Pengeluaran (Y).}

Berdasarkan hasil analisis diperoleh kenyataan bahwa terdapat hubungan yang sangat tinggi antara variabel reward $\left(\mathrm{X}_{1}\right)$ dengan kepuasan kerja bendahara pengeluaran (Y). Hasil analisis ini sejalan dengan Nugroho (2006:5) Reward adalah ganjaran, hadiah, penghargaan atau imbalan yang bertujuan agar seseorang menjadi lebih giat lagi usahanya untuk memperbaiki atau meningkatkan kinerja yang telah dicapai.

Dengan adanya reward akan timbul kepuasan pada pegawai dimana pada akhirnya akan membuat pegawai menjadi lebih produktif serta akan mencegah timbulnya rasa frustasi serta rendahnya kepuasan kerja pegawai.

Reward sangat berperan dalam meningkatkan kepuasan pegawai, karena reward adalah salah satu bentuk penilaian positif terhadap pegawai atas prestasi maupun hasil kerja yang dilakukan oleh pegawai. Sehingga apabila reward ditingkatkan maka kepuasan kerja bendahara pengeluaran akan meningkat pula.

\section{B. Pengaruh Punishment $\left(\mathbf{X}_{2}\right)$ terhadap Kepuasan Kerja Bendahara Pengeluaran (Y).}

Berdasarkan hasil analisis diperoleh kenyataan bahwa terdapat hubungan yang sangat tinggi antara variabel punishment $\left(\mathrm{X}_{2}\right)$ dengan kepuasan kerja bendahara pengeluaran (Y). Hasil penelitian ini sejalan dengan Mangkunegara (2000:130) bahwa "punishment adalah ancaman hukuman yang bertujuan untuk memperbaiki kinerja karyawan pelanggar, memelihara peraturan yang berlaku dan memberikan pelajaran kepada pelanggar".

Punishment sangat berperan meningkatkan kepuasan kerja, karena apabila punishment dijalankan secara baik maka secara otomastis akan mampu menekan tingkat kesalahan dalam bekerja sehingga akan berpengaruh terhadap kepuasan kerja, dan punishment bertujuan untuk membuat pegawai takut dalam melakukan kesalahan dan juga membawa pegawai kearah yang positif, semakin tinggi punishment maka semakin tinggi pula kepuasan kerja bendahara pengeluaran.

\section{Pengaruh Reward $\left(\mathrm{X}_{1}\right)$ dan Punishment $\left(\mathbf{X}_{2}\right)$ terhadap Kepuasan Kerja Bendahara Pengeluaran (Y).}

Berdasarkan hasil analisis diperoleh kenyataan bahwa terdapat hubungan yang sangat tinggi antara variabel reward $\left(\mathrm{X}_{1}\right)$ dan punishment $\left(\mathrm{X}_{2}\right)$ terhadap kepuasan kerja bendahara pengeluaran (Y) Hasil penelitian ini sejalan dengan Dharma (1991:17) bahwa faktor yang mempengaruhi kepuasan adalah pengharapan yang dibebani konsekuensi ( Reward dan Punishment ).

Reward merupakan satu bentuk penilaian positif terhadap kinerja pegawai yang berprestasi sehingga pegawai akan merasa puas dengan hasil kinerja yang mereka kerjakan, sedangkan Punishment merupakan bentuk penilaian negatif dari setiap pelanggaran atau kesalahan dalam bekerja. 
Dengan adanya pemberian reward dan punishment maka pegawai akan terpacu dalam meningkatkan kinerjanya dan meminimalisir tingkat kesalahan dalam bekerja. Pemberian reward dan punishment yang baik diharapkan dapat memenuhi kebutuhan pegawai dalam bekerja, salah satunya kepuasan kerja yang pada akhirnya akan mendorong pegawai lebih giat bekerja untuk lebih baik dan dapat memberikan kontribusinya secara optimal terhadap pencapaian tujuan organisasi. Semakin tinggi reward dan punishment maka semakin tinggi pula kepuasan kerja bendahara pengeluaran.

\section{Pengaruh Kepuasan Kerja (Y) tehadap Kinerja Bendahara Pengeluaran $(\mathbf{Z})$.}

Berdasarkan hasil analisis diperoleh kenyataan bahwa terdapat hubungan yang sedang antara kepuasan kerja (Y) dengan kinerja bendahara pengeluaran (Z). Hasil penelitian ini sejalan dengan Newstrom dan Davis (2007:261) menyatakan bahwa kinerja yang tinggi membentuk kepuasan kerja yang tinggi dan Beck (2010: 347) berdasarkan pendapat Mc Cormick dan Ilgen menyatakan bahwa kepuasan kerja ditentukan oleh sikap seseorang terhadap pekerjaannya.

Kepuasan kerja menunjukkan adanya kesesuaian antara harapan seseorang dengan pekerjaan melibatkan aspek-aspek seperti upah atau gaji yang diterima, kesempatan pengembangan karir, hubungan dengan pegawai lainnya, penempatan kerja, jenis pekerjaan, struktur organisasi dan mutu pegawai.

Jadi dengan demikian bahwa kepuasan kerja merupakan faktor yang mempengaruhi kinerja. Kepuasan kerja merupakan salah satu ukuran dari kualitas kehidupan dalam organisasi dan akan menjadi prediksi yang tidak baik apabila kepuasan kerja tidak menyebabkan peningkatan kinerja. Semakin tinggi kepuasan kerja maka semakin tinggi pula kinerja bendahara pengeluaran.

\section{SIMPULAN}

Berdasarkan pembahasan dari hasil penelitian maka dapat disimpulkan beberapa hal sebagai berikut:

1) Berdasarkan tanggapan responden mengenai reward dengan nilai tertinggi pada indikator intrinsik. Artinya reward sangat dipengaruhi oleh indikator intrinsik. Reward berpengaruh terhadap kepuasan kerja bendahara pengeluaran. Artinya jika reward ditingkatkan, maka kepuasan kerja bendahara pengeluaran akan meningkat pula. Dengan demikian hipotesis 1 dapat teruji kebenarannya atau Signifikan karena $t_{\text {hitung }}>t_{\text {tabel }}$ dengan $p$-Value 0,001 .

2) Berdasarkan tanggapan responden mengenai punishment dengan nilai tertinggi pada indikator preventif. Artinya punishment sangat dipengaruhi oleh indikator preventif. Punishment berpengaruh terhadap kepuasan kerja bendahara pengeluaran. Artinya jika punishment ditingkatkan, maka kepuasan kerja bendahara pengeluaran akan meningkat pula. Dengan demikian hipotesis 2 dapat teruji kebenarannya atau Signifikan karena $t_{\text {hitung }}>t_{\text {tabel }}$ dengan $p$-Value 0,000 .

3) Berdasarkan tanggapan responden mengenai kepuasan kerja bendahara pengeluaran dengan nilai tertinggi pada indikator faktor psikologi. Artinya kepuasan kerja bendahara pengeluaran sangat dipengaruhi oleh indikator faktor psikologi. Reward dan punishment berpengaruh terhadap kepuasan kerja bendahara pengeluaran. Artinya jika reward dan punishment ditingkatkan, maka kepuasan kerja bendahara pengeluaran akan 
meningkat pula. Dengan demikian hipotesis 3 dapat teruji kebenarannya atau Signifikan karena $\mathrm{F}_{\text {hitung }}>\mathrm{F}_{\text {tabel }}$ dengan $p$-Value 0,000 .

4) Berdasarkan tanggapan responden mengenai kinerja bendahara pengeluaran dengan nilai tertinggi pada indikator tingkat kemampuan pegawai dalam kerjasama dengan yang lain. Artinya kinerja bendahara pengeluaran sangat dipengarahui oleh indikator tingkat kemampuan pegawai dalam kerjasama dengan yang lain. Kepuasan Kerja berpengaruh terhadap kinerja bendahara pengeluaran. Artinya jika kepuasan kerja ditingkatkan, maka kinerja bendahara pengeluaran akan meningkat pula. Dengan demikian hipotesis 4 dapat teruji kebenarannya atau Signifikan karena $\mathrm{t}_{\text {hitung }}>\mathrm{t}_{\text {tabel }}$ dengan $p$-Value 0,000 .

\section{DAFTAR PUSTAKA}

As'ad. (2001). Manajemen Sumber Daya Manusia Psikologi Industri. Bandung : Alumni.

Beck, Robert C., (2010). Motivation, Theories and Principles New Jersey : Prentice Hall.

Bernardin, H. John \& Joyce, E. A Russel. (2003). Human Resource management: an experiential approachs. Singapore : MC. Graw Hill Internasional.

Cahyani, Ati. (2005). Strategi dan Kebijakan Manajemen Sumber Daya Manusia, Jakarta : Indeks.

Dessler, Gary. (2011). Manajemen Sumber Daya Manusia, Jakarta : Prenhallindo.

Handoko T. Hani. (2008). Manajemen Sumber Daya Manusia. Yogyakarta : BPFE.

Hasibuan, Malayu SP. (2005). Manajemen Sumber Daya Manusia (Dasar dan Kunci Keberhasilan. Jakarta : Toko Gunung Agung.

Ivancevich, Konopaske dan Matteson. (2006). Perilaku Manajemen Dan
Organisasi. alih bahasa Gina

Gania. Jakarta : Erlangga.

Mahmudi. (2005). New Publik Management, Pendekatan Baru Manajemen Sektor Publik. Yogyakarta : BPFE.

Mangkunegara, Anwar Prabu. (2009). Manajemen Sumber Daya Manusia. Bandung : Remaja Rosdakarya.

Martoyo, Susilo. (2008). Manajemen Sumber Daya Manusia. Yogyakarta : BPFE.

Mondy R Wayne. (2010). Fundamental Of Human Resource Manajemen. New York : Mc Graw-Hill.

Ndraha, Taliziduhu. (2003). Teori Pengembangan Sumber Daya Manusia. Jakarta: Rineka Cipta.

Newstrom, John W. And Davis, Keith, (2007). Organizational Behavior, Human Behavior at Work Singapore : The McGraw-Hill Book Company.

Noe, Raymond. (2008). Human Resource Manajemen. New York : Mc GrawHill.

Nugroho Riant. (2006). Public Policy. Jakarta : Elex Media Komputindo.

Pearson. (2006). Human Resources Manajemen. New Jersey : Prentice Hall.

Prawirosentono, Suyadi. (2007). Kebijakan Kinerja Karyawan. Yogyakarta : BPFE.

Purwanto, M, Ngalim. (2007). Instrumen Penelitian Sosial dan Pendidikan. Yogyakarta : Pustaka Pelajar.

Rivai Veithzal. (2005). Manajemen Sumber Daya Manusia Untuk Perusahaan. Jakarta : Raja Grafindo Persada.

Robbins, Stephen. P. (2006). Perilaku organisasi. Edisi Bahasa Indonesia. Jakarta : PT Indeks Kelompok Gramedia.

Rusidi dan Enas. (2001). Metode Penelitian (Elaborasi Pedoman Penulisan Skripsi, Tesis dan Disertasi. Bandung : Dewa Ruchi.

Sedarmayanti. (2010). Manajemen Sumber Daya Manusia. Bandung : Refika Aditama.

Simamora, Henry. (2012). Manajemen Sumber Daya Manusia. Yogyakarta : STIE YKPN. 
journal of managementReview

ISSN-P : 2580-4138 ISSN-E 2579-812X http://jurnal.unigal.ac.id/index.php/managementreview

Volume 1 Number 1 Page (33-42)

Soelaiman Sukmalana. (2007). Manajemen

Kinerja Langkah-langkah efektif

Untuk Membangun, Mengendalikan

dan Evaluasi Kerja. Jakarta.

Intermedia Personalia Utama

Sofyandi, Herman. (2008). Manajemen

Sumber Daya Manusia.

Yogyakarta : Graha Ilmu.

Sugiyono. (2010). Metode Penelitian Administrasi. Bandung : Alfabeta.

Sunyoto, Agus. (2011). Manajemen Sumber Daya Manusia. Jakarta : IPWI.

Surakhmad, Winarno. (1990). Pengantar Penelitian-penilitian Ilmiah. Bandung : Tarsito.

Sutrisno, Edy. (2009). Manajemen Sumber Daya Manusia. Jakarta : Kencana.

Umar, Husein. (2003). Riset Sumber Daya Manusia dalam Organisasi. Jakarta : Gramedia Pustaka Utama. 